\title{
ИСТОРИЧЕСКИЕ ЗАПИСКИ
}

DOI: $10.17805 /$ zpu.2017.2.20

\section{Трансформация органов власти Казанской губернии после Февральской революции}

\author{
Е. В. МИРОНОВА
}

\author{
ИНСТИТУТ ИСТОРИИ ИМ. Ш. МАРДЖАНИ АКАДЕМИИ НАУК РЕСПУБЛИКИ ТАТАРСТАН
}

Статья посвящена проблеме реорганизации власти в Казанской губернии после событий февраля 1917 г. в России. В общих чертах реорганизация была закончена весной, но отдельные изменения в системе управления продолжались до Октябрьской революции. Актуальность статьи определяется недостаточной изученностью трансформации власти в регионах, и в частности в Казанской губернии.

На основании материалов периодической печати и архивных документов изучены становление и развитие как новых институтов власти на местах - комиссаров Временного правительства, комитетов общественной безопасности и Советов, так и развитие прежних органов самоуправления - земств и городских дум. Основной институт власти, на который опиралось Временное правительство, - комиссары - оказался неспособным проводить требуемую политику. Органы самоуправления в течение весны 1917 г. сделали попытку демократизации. В их состав были введены представители низов, но, не обладая необходимым опытом управления, они продолжали подчиняться буржуазии и землевладельцам, стоявшим во главе этих учреждений. Советы, как и комиссары, должны были удовлетворять чаяниям крестьян и пролетариев, а также бороться с зажиточной частью населения, не хотевшей усиления революции. Совет крестьянских депутатов губернии занял радикальную позицию и прямо нарушал постановления правительства.

Автор сделал вывод, что местные органы управления, проводя неуверенную политику Временного правительства, не смогли удовлетворить потребности населения в решении земельного и продовольственного вопросов, обеспечении безопасности. В итоге буржуазия и дворянство потеряли авторитет и уступили позиции выходцам из «низов». Последние и пришли к власти в результате Октябрьской революции 1917 г.

Ключевые слова: Казанская губерния; 1917 г.; Февральская революция; Октябрьская революция; Временное правительство; комитет общественной безопасности; Советы; органы местного самоуправления; история Татарстана

\section{ВВЕАЕНИЕ}

B феврале 1917 г. совокупными усилиями различных общественных сил в России была свергнута монархия, уже не удовлетворявшая экономическому, политическому и социальному развитию страны. Очаг революции располагался в Петрограде, однако если бы переворот не был поддержан в провинции, царская власть могла устоять. В регионах столкнулись интересы местной элиты, низов общества и Временного правительства. Преобразования органов власти отражают эти процессы и показывают, как революция меняла политический облик глубинки. 
Одним из таких регионов является Казанская губерния, которая к 1917 г. представляла собой сельскохозяйственный регион со слабо развитой промышленностью, сосредоточенной в основном в губернском городе. Аворянское землевладение было не столь обширным, как, например, в соседней Самарской губернии, но дворянство было сплоченным, играло большую роль в общественной жизни и имело значительное влияние в земских органах. Еще одна особенность заключалась в расположении в Казани управления обширного Казанского военного округа, включавшего в себя Казанскую, Пермскую, Вятскую, Пензенскую, Симбирскую, Саратовскую и Астраханскую губернии. Также стоит отметить полиэтничность региона, что требовало от властных структур учитывать не только потребности различных классов, но и интересы различных национальностей.

На примере Казанской губернии, как типичной для Европейской России, можно показать смену органов власти после Февральской революции в провинции. Изучение этого процесса поможет лучше понять цели Временного правительства и способы их реализации, а также ожидания и требования местного населения от власти.

\section{ПЕРЕХОА ВААСТИ К ВРЕМЕННОМУ ПРАВИТЕАЬСТВУ}

К началу Февральской революции в губернии, по жандармским отчетам, все было спокойно. Население критиковало власть за высокие цены, недостаток продуктов и войну, но весьма умеренно. В основном ругали низших чиновников, а к губернской администрации и верховной власти относились с доверием (Алексеев, 2012: Электронный ресурс). Пост губернатора тогда занимал П. М. Боярский, обладавший большим опытом административного управления.

В конце февраля Боярский оказался в Москве, откуда он собирался ехать в Петроград, чтобы увидеть все новости самому, но революционная неразбериха не позволила выполнить задуманное. 2 марта он вернулся в Казань и телеграфировал председателю Государственной думы Родзянко и члену Аумы от Казанской губернии Годневу просьбу сообщить, сохраняются ли за ним полномочия губернатора, и в таком случае дать необходимые указания (Национальный архив Республики Татарстан - далее НА РТ. Ф. 1246. Оп. 1. А. 27. А. 8). В тот же день он рассылает циркуляры во все города и земства губернии с просьбой сохранять спокойствие. Именно после возвращения Боярского органы власти в Казанской губернии меняют курс с противодействия революции на ее поддержку. 3 марта Временный комитет Государственной думы признают Казанская городская дума и командующий Казанским военным округом Сандецкий, а затем следует череда телеграмм в Петроград от различных казанских общественных, политических, образовательных и прочих учреждений с поздравлениями новой власти.

Губернатор, несомненно, хотел остаться на своем посту, и местная власть его в этом желании поддерживала. Казанская городская дума в заседании 3 марта постановила не обсуждать вопрос о смене местной власти до особых распоряжений и признавать полномочия Боярского (Городская дума, 1917: 3). А губернский предводитель дворянства С. С. Толстой-Милославский просил губернатора от имени земского собрания оставаться на своем посту (Организация Комитета ..., 1917: 3).

Как губернатор Боярский обладал колоссальным опытом, который мог бы пригодиться в тяжелых переходных условиях, кроме того, он не вызывал неприязни у населения. Но общество требовало перемен, и Временное правительство должно было прислушиваться к его мнению. 6 марта телеграммами телеграфных агентств в печати 
было сообщено об упразднении должности губернатора и передаче его полномочий председателю губернской земской управы (НА РТ. Ф. 1246. Оп. 1. А. 27. А. 35).

После отрешения от должности Боярский срочно уезжает из Казани (НА РТ. Ф. 1246. Оп. 1. А. 27. $\Lambda .65)$, возможно, опасаясь репрессий. Официально он все еще оставался губернатором вплоть до 1 мая. Тогда по распоряжению Временного правительства губернаторы и вице-губернаторы должны были написать прошение об отставке, с назначением пенсии, которую установит правительство.

\section{ИНСТИТУТ КОМИССАРОВ ВРЕМЕННОГО ПРАВИТЕАЬСТВА}

Взамен губернаторов правительством на местах был создан институт комиссаров. По словам председателя Временного правительства князя Г. Е. Аьвова, комиссары были лишь посредниками между центральной властью и создавшимися местными органами власти, чтобы облегчить процесс их оформления (Кабытова, 1999: 65). Однако создавшиеся иногда стихийно общественные комитеты не признавались органами власти (Мансуров, 2006: 31), и над ними ставились комиссары, через которых можно было проводить политику Временного правительства непосредственно. Причем правительство утверждало не только губернских комиссаров, но и уездных, таким образом стремясь контролировать губернии как можно полнее.

Выбор в качестве комиссаров председателей земских управ был не случаен. С одной стороны, это были демократически избранные представители народа, с другой они не были радикально настроенными революционерами, и большинство из них придерживались либеральных взглядов, как и министры Временного правительства.

За время нахождения у власти Временного правительства в Казанской губернии сменилось три комиссара: В. В. Молоствов, А. Н. Плотников, В. А. Чернышев. Избрание председателя Казанского губернского земского собрания состоялось лишь накануне его назначения комиссаром - 5 марта. Им стал Александр Николаевич Плотников. Однако утверждение в должности произошло только 30 марта. Ао этого момента его обязанности исполнял В. В. Молоствов.

Согласно указанию Временного правительства губернские комиссары сохраняли все полномочия губернатора, при этом они оставались на посту председателей губернских земских управ и выполняли свои обязанности (НА РТ. Ф. 1246. Оп. 1. А. 27. 1. 49). Комиссары выполняли главным образом контролирующую функцию: улаживали споры, следили за исполнением законов и обеспечением продовольствием.

Губернские комиссары обязаны были беспрекословно слушаться верховную власть, но самые ответственные вопросы им приходилось решать самим. Так, министр внутренних дел разъяснял, что вопрос о применении вооруженных сил для предотвращения насилия и грабежей находится в ведении губернских комиссаров и должен решаться ими по согласованию с военными властями. Также комиссары занимались разъяснениями спорных вопросов, улаживали конфликты с другими властными органами. Сельские и волостные комитеты действовали зачастую без оглядки на законы и самовольно отбирали землю у помещиков, пользовались близлежащими лугами и лесами.

Кроме того, на губернском комиссаре лежали обязанности председателя земской управы. Естественно, совмещение этих постов требовало полной самоотдачи, что не всякий мог выдержать. А. Н. Плотников уже во время избрания его председателем губернской земской управы хотел отказаться от баллотировки, назначение же его на пост руководителя губернии оказалось ему явно не по силам. 19 мая он обращается 
в MBA, где сообщает, что по состоянию здоровья больше не может нести свои обязанности и передает их своему заместителю Чернышеву.

Губернский комиссар являлся председателем губернского комитета общественной безопасности (КОБ). Однако это положение было введено позже, между тем сам комитет образовался еще 4 марта, по инициативе губернатора Боярского, который предложил казанскому городскому голове В. А. Боронину создать небольшой общественный комитет из гласных думы. Боярский предполагал, что это учреждение будет только контролировать действия полиции, но оно объединило разнородные общественные силы и стало наиболее демократичным органом власти того времени. Первоначально председателем КОБа стал Боронин, но затем его возглавил комиссар Временного правительства. На первое организационное совещание 5 марта явились представители Военного комитета, города, земства, Совета рабочих депутатов, университета, адвокатуры, врачей, кооперативов и других организаций.

15 апреля в инструкции по организации временного административного управления Казанской губернии, принятой самим же губернским КОБом, уже четко определялось, кто в него входит. Это были председатель в лице губернского комиссара и два его заместителя. Основную массу составляли представители различных организаций и общественных групп: земства, городского самоуправления, профсоюзов, социалистических партий, национальных и религиозных организаций (НА РТ. Ф. 1246. Оп. 1. А. 30. А. 39).

Комитет общественной безопасности, как и следует из его названия, следил за спокойствием в губернии, контролировал создание полиции, направлял своих членов в уезды, где происходили волнения, занимался агитацией в пользу Временного правительства. Но в целом КОБ не являлся самостоятельной силой и подчинялся губернскому комиссару (Мансуров, 2006: 53). Основную тяжесть работы на местах несли уездные комиссары и возглавляемые ими комитеты общественной безопасности. В информационном отделе по местному управлению указывалось, что задачи уездных комиссаров состоят в содействии Временному правительству, чтобы вести общество к построению нового строя и созданию наиболее благоприятных условий для работы всех учреждений (там же: 35$)$.

Согласно распоряжению Временного правительства, в уездные комиссары должны были назначаться председатели уездных земских управ и утверждаться в Петрограде. Однако уездные комиссары были ближе к населению, чем губернский, народ реагировал на их решения более чутко, и на этих постах зачастую оказывались люди, которые пользовались доверием местных граждан, а не правительства. Поэтому губернский комиссар часто вместо выбранных населением ставил своих назначенцев. Но правительство такую политику не поддержало, и 28 апреля МВА направило губернскому комиссару циркуляр, в котором говорилось о снижении авторитета Временного правительства в результате частого смещения его представителей на местах. Министерство просило назначать на эти посты людей, пользующихся авторитетом у населения.

Примером подобного неверного назначения может служить инцидент в городе Царевококшайске, где после сложения своих обязанностей председателя земской управы Ящерицына на должность комиссара был назначен его заместитель Казаков. Аля упрочения своей власти он решил распустить местный комитет общественной безопасности, что естественно вызвало возмущение его членов. Они направили запрос губернскому комиссару, в котором указывали, что выполнение такого предло- 
жения противоречит указаниям правительства и может вызвать открытое выступление народа и что Казаков не пользуется доверием населения (НА РТ. Ф. 1246. Оп. 1. А. 27. $\Lambda .184)$.

Губернский комиссар не стал вступаться за своего ставленника и разрешил созыв экстренного земского собрания для выбора нового председателя управы (НА РТ. Ф. 1246. Оп. 1. А. 27. А. 187). Но собрание не только избрало нового председателя известного в городе общественного деятеля и бывшего земского гласного И. А. Аружинина, но и нового комиссара, таким образом нарушив распоряжение правительства о соединении должностей председателя управы и комиссара в одном лице. Им стал уездный член окружного суда В. П. Барановский (Руководящие указания ..., 1917: 3 ).

Иногда местные органы власти, организованные не указом сверху, а путем народного волеизъявления, практически в открытую противились распоряжениям Временного правительства. В Чебоксарах на митинге, устроенном большевиками И. Н. Ивановым и К. Я. Грасисом, толпа под влиянием их речей начала требовать отставки комиссара Эннатского за его реакционность. Тут же были выбраны представители, которые отправились на квартиру комиссара и заставили его написать отречение (Иванов, 1923: 60).

Перед уездными комиссарами стояли практически те же задачи, что и перед губернскими. Они должны были сдерживать инициативу волостных и сельских комитетов, когда те выходили за рамки закона и начинали самостоятельно решать земельный и продовольственный вопросы, захватывая частновладельческие земли, скот и сельскохозяйственную продукцию. Чтобы обладать угрозой применения силы, сразу после назначения комиссарам следовало организовать милицию для охраны порядка, но им предписывалось действовать путем переговоров, объясняя населению, что вопрос раздела помещичьих земель подлежит ведению Учредительного собрания (НА РТ. Ф. 1246. Оп. 1. А. 30. А. 415).

Уездные комиссары, как уже было сказано выше, являлись председателями уездных комитетов общественной безопасности. С приходом к власти председатель уездного земства должен был организовать временный совет. Выборщики созывались комиссаром на общее собрание и вместе с временным советом избирали постоянный совет из девяти лиц (НА РТ. Ф. 1246. Оп. 1. А. 27. А. 54). В процессе становления новой власти состав комитета расширялся, и к середине апреля в него входили делегаты от каждой волости, а также от земства, города, рабочих и других общественных уездных организаций (НА РТ. Ф. 1246. Оп. 1. А. 30. А. 39). Хотя уездные комитеты обладали меньшими полномочиями по сравнению с губернским, они пользовались большей самостоятельностью и не всегда подчинялись комиссарам.

В волостях и отдельных селениях также организовывались комиссары и комитеты, но контроль за ними со стороны верховной власти практически отсутствовал. Волостные комитеты заменяли бывшие волостные правления и волостных старшин. Согласно выработанному к 15 апреля положению, волостные комитеты организовывались путем введения в его состав не менее одного лица от каждого селения и по одному представителю от каждого кооператива, работающего в пределах волости (НА РТ. Ф. 1246. Оп. 1. А. 30. А. 39 об). Однако назначение председателей волостных комитетов общественной безопасности зачастую происходило не по сценарию правительства. Например, в Жедяевской волости Спасского уезда им стал прибывший туда во время революции В. Т. Одинцов, который был избран волостным комитетом без участия вышестоящих органов власти (Аокументы по истории ..., 1973: 155-158). 
Чем дальше от центральной власти, тем демократичней были порядки, но и сильней анархия. Так, в сентябре в Спасском уезде Трехозерский волостной комитет объявил свою республику и перестал слушать уездное начальство. В Ааишевском уезде председатель Урахчинского волостного комитета отказался исполнить распоряжения правительства, а председатель волостного комитета Иванов оказал сопротивление вооруженной команде и арестовал представителя губернского комиссара Степанова (Валеев, 1968: 222).

Волостные комиссары из низов встречали противодействие со стороны как зажиточных слоев населения, так и деревенских низов. В. Т. Одинцов под давлением солдат и бедноты вынужден был отобрать у помещиков рабочих лошадей, так как они стояли без работы, а крестьяне в них нуждались (Аокументы по истории ..., 1973: 160).

На волостном собрании 28 мая кулаки стали требовать его смещения, но и сам Одинцов просил отставку, поскольку «сильно истрепался, заболел от тяжести работы» (там же: 161).

Институт комиссаров согласно первоначальному замыслу должен был выстроиться в систему власти, пронизывающую губернии сверху донизу, позволяя Временному правительству контролировать положение дел на местах. Однако в Казанской губернии полную лояльность проявляли только губернские комиссары, а на уровне волостей и сел и вовсе проявляли своеволие и неподчинение правительственным указам. Такое положение объясняется отчасти слабостью Временного правительства, отчасти стихийным движением масс.

\section{ОРГАНЫ САМОУПРАВАЕНИЯ}

После Февральской революции продолжали действовать городские и земские органы самоуправления. Ао 1917 г. они выполняли лишь хозяйственные функции, теперь стали все активнее вовлекаться в политическую жизнь. С одной стороны, их формирование происходило выборным путем, что удовлетворяло демократическим требованиям того времени, с другой - у них имелся богатый опыт хозяйствования. Поэтому в первые дни революции во многих городах, в том числе Казани, думы и городские головы стали организаторами комитетов общественной безопасности, а председателей земских управ назначили комиссарами Временного правительства.

Казанский городской голова В. А. Боронин, избранный в 1913 г., поначалу пользовался большим успехом и в марте новым составом думы был переизбран. Но ему не посчастливилось быть товарищем председателя Казанского губернского и городского продовольственных комитетов. В июне в Казани произошли беспорядки, толпа граждан явилась к зданию продовольственной управы и стала требовать Боронина, которого обвиняли в продовольственном кризисе. Когда тот явился, его самовольно арестовали. Местный Совет выступил в его защиту и признал арест незаконным, но после этого авторитет городского головы сильно пошатнулся (Мансуров, 2006: 29).

Хотя гласные городских дум избирались и до революции, но довольно высокий имущественный ценз не позволял большинству горожан участвовать в выборах. Поэтому на протяжении всего периода с февраля по октябрь велась работа по расширению их состава. Уже 21 апреля состоялось первое заседание обновленной Казанской городской думы. Она состояла из 80 гласных и двух представителей от Казанского уездного земства и духовного ведомства. Большинство мест в городской думе занимала буржуазия, что не понравилось беднейшим слоям населения. Поэтому деятельность по демократизации общественных управлений продолжалась. 
В итоге Временным правительством были выработаны новые правила выборов: на основании прямого, всеобщего, равного и тайного избирательного права, без различия пола, вероисповедания и национальности; избирательный возраст устанавливался в 20 лет; в избирательные списки вносились все проживающие или имеющие оседлость в городе во время составления списков (Хроника, 1917а: 3). Это положение существенно расширило электорат, и в списках избирателей в Царевококшайске 18 июня уже числилось 1200 человек, что составляло почти половину населения города, в том числе молодых людей до 20 лет, которым не позволено было голосовать. Пришли на выборы чуть больше половины из них. В состав думы избрали 20 гласных, из которых были 2 женщины (Царевококшайск ..., 1917: 3).

Земства после известия о смене власти в Петрограде, в отличие от городских управлений, не стали проявлять инициативы. На заседании чрезвычайного губернского земского собрания 5 марта были избраны кандидаты в комитет общественной безопасности. Ими стали в основном дворяне-землевладельцы (Начальник городской милиции, 1917: 4).

Инициативу по демократизации губернского земского собрания взяли на себя комитет общественной безопасности и губернский комиссар, который являлся также и председателем земской управы. 24 апреля на заседании КОБа было решено пополнить состав собрания членами различных общественных организаций, политических партий, профсоюзов и т. А. (Хроника, 1917b: 3).

Но такое расширение состава собрания понравилось не всем гласным. Некоторые из них выступили резко против и обвинили комиссара в нарушении предписаний Временного правительства, указав на чрезмерное пополнение и увольнение из состава собрания представителей казны. В знак протеста некоторые гласные покинули собрание. Телеграмма об этом происшествии была направлена министру внутренних дел и государственному контролеру Годневу (Телеграмма группы ..., 1917: 3), который являлся выходцем из Казанской губернии и был бывшим гласным земского собрания.

В этом противостоянии верх одержали представители земства, а комиссару было велено созвать экстренное собрание, куда избрать от каждого уездного земского собрания указанное в расписании число гласных, позволив, кроме того, участвовать в собрании гласным прежнего состава. Отмечалось, что представители казны и ведомств не могут быть устранены из собрания, в крайнем случае оно может быть пополнено членами губернских национальных организаций (В губернском земстве, 1917: 3).

C помощью земств правительство также пыталось вернуть контроль над волостями. 21 мая было принято временное положение о волостном земском управлении. Они заменяли различные волостные комитеты, выносившие самовольные решения, служившие постоянной головной болью для центральной власти. Выборы проходили на основании всеобщего, равного, прямого и тайного голосования лицами, достигшими возраста 20 лет (Волостное земство, 1917: 3). Если прежние волостные комитеты организовывались практически без участия правительства, то волостные земства должны были утверждать некоторые решения в уездных земствах. Например, вопросы об отчуждении имущества, что позволяло ограничить принятие противозаконных решений об отъеме земли, скота и инвентаря у частных владельцев.

Организация новых земских отделений началась осенью. В состав новых земских органов входили в основном крестьяне, которые не обладали необходимым опытом управления. Их создание началось практически перед Октябрьской революцией, и за этот период они не успели себя проявить. 
Земские и городские органы самоуправления показали себя лояльными новому правительству. Но как активная политическая сила они себя почти не проявили, подчиняясь воле комиссаров и выполняя по-прежнему хозяйственные функции. Хотя их состав расширялся, однако во главе оставались старые земцы и городские гласные, во многом благодаря своему опыту в хозяйственных делах.

\section{СОВЕТЫ}

О деятельности Советов в Казанской губернии сохранилось не так много материалов. Возможно, это объясняется меньшей бюрократией по сравнению с органами власти Временного правительства и, соответственно, меньшей документированностью их действий. У Советов не было строго исполнительного аппарата, и они действовали через выборных представителей, ведя больше политическую деятельность (Мансуров, 2006: 42).

2 марта был создан Совет рабочих депутатов, 7 марта - Совет солдатских депутатов, которые 14 марта слились. Первым председателем объединенного Совета стал подпоручик К. Б. Поплавский. В Казанской губернии Советы, как и в России в целом, не всегда ладили с представителями Временного правительства. Совет крестьянских депутатов, образованный в мае, уже 13 мая выпускает постановление, согласно которому частновладельческие земли, скот и инвентарь могли конфисковать, не дожидаясь созыва Учредительного собрания. Такое решение противоречило самым основам нового строя и вызвало бурную реакцию со стороны губернского комиссара. В уездах постановление стало реализовываться в июне. Комиссар Чернышев просил уездных комиссаров принять меры, чтобы данная резолюция не приводилась в исполнение, и разъяснить населению, что окончательное решение земельного вопроса зависит от Учредительного собрания, до того данным вопросом занимаются земельные комитеты. Совет рабочих и солдатских депутатов также в целом негативно отнесся к этому постановлению. На соединенном собрании Совета рабочих, солдатских и крестьянских депутатов было принято решение собрать по этому поводу съезд с участием уездных и волостных комиссаров, представителей продовольственных комитетов губернии и земельных комитетов (Борьба с анархией ..., 1917: 3).

Но и сами Советы не всегда могли контролировать население. 2 мая солдаты самовольно перевели бывшего командующего Казанским военным округом арестованного генерала Сандецкого из лазарета на гауптвахту, при этом оскорбляя его. Председатель Совета рабочих и солдатских депутатов К. Б. Поплавский заявил, что покидает Совет и слагает с себя обязанности председателя, раз солдаты ему не подчиняются (Хроника, 1917с: 3). На этот раз его уговорили остаться на своем посту, но уже на следующий день произошел очередной инцидент, когда вместо тысячи солдат, назначенных к отправке на фронт, явились лишь триста. Поплавский решил показать на своем примере необходимость продолжения войны и сам отправился на фронт (Мансуров, 2006: 41). Его место занял прапорщик Голанов, практически не имевший опыта управления.

Уездные Советы организовывались позже губернского, в некоторых местностях их не было до Октябрьской революции. В Царевококшайском уезде Совет крестьянских депутатов образовался 1 июля. В состав Совета вошли по одному представителю от волости и от трудового мещанства города. Также с правом совещательного голоса в его работе приглашены представители Учительского съезда. Председателем был избран П. И. Мочалов, бывший руководителем Крестьянского союза в 1905 г. Однако 
уже на втором съезде Совета 15 августа он отказался от должности, и на его место был избран некто Голиков. Но и он продержался лишь полмесяца и на третьем съезде 1 сентября был отстранен из-за прежней службы. Следующим председателем стал И. Н. Коведяев. От назначенного ему жалованья в 180 рублей он отказался, но собрание определило ему в виде вознаграждения 50 рублей в месяц (НА РТ. Ф. Р-983. Оп. 1. A. 18. А. 34).

В начале своей деятельности уездные советы решали прежде всего продовольственный и земельный вопросы - направляли своих представителей в продовольственный и земельный комитеты и добивались перехода земли и инвентаря в их ведение. Постоянно не хватало работников на местах, поэтому в некоторых волостях Советы так и не были организованы и не велась работа по исполнению постановлений вышестоящих отделений. Чтобы восполнить недостачу кадров, председателю и инструкторам часто приходилось ездить самим по всему уезду (НА РТ. Ф. Р-983. Оп. 1. А. 18. А. 35).

Товарищ председателя Казанского губернского комитета общественной безопасности А. Н. Нехотяев отмечал, что исполком согласовывал свою деятельность с СРСА и никакого двоевластия нет (В комитете общественной безопасности, 1917: 3), на деле оказывалось, что некоторые противоречия все же имелись. Самое крупное расхождение во взглядах вышло из-за постановления 13 мая о передаче частновладельческих земель крестьянам, но были и мелкие разногласия. Советы хотели участвовать в назначении местных органов власти. Ааишевский совет крестьянских депутатов через Губернский совет требовал сменить начальника милиции и комиссара, назначенных губернским КОБом, на кандидатов, пользующихся уважением народа. Также конфликты выходили из-за отдельных личностей, занимающих ту или иную должность. В целом хорошие отношения между губернским земельным комитетом и Советом крестьянских депутатов были подпорчены неким Барсуковым, являвшимся членом комитета и Совета. Он начал варить кумышку (самогон), чем вызвал неудовольствие членов общества и был отрешен от всех должностей. Однако при перевыборах он прошел в члены уездной земельной управы, Совет начал настаивать на его удалении, из-за чего проявилось взаимное неудовольствие между управой и Советом. После снятия Барсукова отношения вновь наладились (НА РТ. Ф. 1246. Оп. 1. А. 17. А. 41 об.).

\section{ЗАКАЮЧЕНИЕ}

В феврале - марте 1917 г. была коренным образом переустроена система государственного управления страной. Ранее для России был характерен традиционный тип власти, при котором лица, занимающие определенные должности и имеющие определенный статус, считались законными руководителями. После революции политическое лидерство стало важнейшим механизмом формирования органов власти (Халилова, 2000: 37). Однако пережитки прошлого продолжали чувствоваться и в новых условиях. Властные органы Казанской губернии, призванные объединить и направить общественные силы в русло политики Временного правительства, не справились с этой задачей. Вынужденные лавировать между правительственными распоряжениями и настроениями толпы, они не угодили ни тем, ни другим.

Казанская губерния не относилась к числу промышленно развитых губерний, социальные и политические проблемы здесь не отличались остротой. Но все же процесс перехода власти к новому правительству был типичен для большинства регионов России, что позволяет сделать выводы о функционировании властных органов после Февральской революции в стране в целом. За этот период «низы» общества, получив 
доступ во власть, приобрели некоторый опыт управления, что сыграло положительную роль после Октябрьской революции. Приучившись к попустительству и слабости правительства, они привыкли полагаться на свои силы. Но это же привело и к излишней самоуверенности, в результате чего они перестали прислушиваться к доводам оппонентов. Кроме того, авторитарное мышление так и не было изжито, что в дальнейшем и привело к новому витку свертывания демократии.

\section{СПИСОК АИТЕРАТУРЫ}

Алексеев, И. Е. (2012) Революционные события февраля - марта 1917 г. в Казани: реакция верхов [Электронный ресурс] // Русская народная линия. Информационно-аналитическая служба. 25 апреля. URL: http://ruskline.ru/analitika/2012/04/25/revolyucionnye_sobytiya_fevralya_marta_1917_g_v_kazani_reakciya_verhov/ (дата обращения: 03.10.2016).

Борьба с анархией в Казанской губернии (1917)// Камско-Волжская речь (газета). № 127. С. 3.

В губернском земстве (1917) // Камско-Волжская речь (газета). № 128. С. 3.

В комитете общественной безопасности (1917) // Камско-Волжская речь. №92. С. 3.

Валеев, Р. К. (1968) Революционное движение в Среднем Поволжье в период назревания общенационального кризиса (июль - октябрь 1917 г.) : дис. ... канд. ист. наук. Казань. 329, XXVII, 10 с.

Волостное земство (1917) // Камско-Волжская речь (газета). №116. С. 3.

Городская дума (1917) // Камско-Волжская речь (газета). № 49. С. 3.

Аокументы по истории Октября в Татарии (1973) / под ред. И. М. Ионенко. Казань : Татарское книжное издательство. 212 с.

Иванов, И. Н. (1923) Как мы работали // Коммунистический путь. №2 (22). С. 64-65.

Кабытова, Н. Н. (1999) Власть и общественные организации Поволжья в 1917 году : дис. ... А-ра ист. наук. Самара. 462 с.

Мансуров, Р. 3. (2006) Февральская революция в Казанской губернии как фактор новой общественно-политической ситуации в крае : дис. ... канд. ист. наук. Казань. 188 с.

Начальник городской милиции (1917) // Камско-Волжская речь (газета). №53. С. 4.

Организация Комитета общественной безопасности в Казани (1917) // Камско-Волжская речь (газета). №52. С. 3.

Руководящие указания правительства об устроении местной власти (1917) // Камско-Волжская речь (газета). №63. С. 3 .

Телеграмма группы губернских гласных (1917)// Камско-Волжская речь (газета). № 107. С. 3.

Халилова, Т. В. (2000) Региональное лидерство и политическая культура (на материалах Казанской губернии). Февраль 1917 - июль 1918 гг. : дис. ... канд. ист. наук. Казань. 205 с.

Хроника (1917а) // Камско-Волжская речь (газета). № 86. С. 3.

Хроника (1917b) // Камско-Волжская речь (газета). № 89. С. 3.

Хроника (1917c) // Камско-Волжская речь (газета). №98. С. 3.

Царевококшайск. Городские выборы (1917) // Камско-Волжская речь (газета). № 138. С. 4.

Аата поступления: 27.01.2017 2.

TRANSFORMATION OF AUTHORITIES

IN KAZAN PROVINCE AFTER THE FEBRUARY REVOLUTION

\section{E. V. MIRONOVA}

\section{Sh. Marjani Institute of History, Academy of SCIences, Republic of Tatarstan}

The article deals with the problem of reorganization of power in Kazan province after the events of February 1917 in Russia, which in general was completed in the spring, but some changes in the management system continued until the October revolution. The relevance of the article is defined by insufficient study of the transformation of power in the regions and in particular in Kazan province.

The formation and development of new institutions of power like local authorities - the commissioners of the Provisional Government, Public Safety Committees and Soviets - and the development 
of previous governments - Zemstvos and municipal dumas were studied on the basis of materials of periodicals and archive documents. The basic institution of power, which the Provisional government relied on, that is the commissioners, turned out to be unable to carry out the required policy. Selfgovernment bodies during the spring of 1917 made an attempt to democratize. They were composed of representatives of the lower classes, but lacking the necessary management experience, they continued to submit to the bourgeoisie and the landowners, who stood at the head of these institutions. Soviets, as well as commissioners, had to satisfy the aspirations of the peasants and the proletarians, but also to deal with the wealthy part of the population, not desiring to strengthen the revolution. The council of Peasants' Deputies took a radical position and directly violated government regulations.

The author concluded that local governments, while carrying out the uncertain policy of the Provisional Government, failed to meet the needs of the population in solving land issues and the problems of food supply and security. As a result, the bourgeoisie and the nobility lost authority and lost positions to people from the "bottom", who came to power after the October revolution of 1917.

Keywords: Kazan Province; 1917; February Revolution; October Revolution; Provisional Government; Committee of Public Safety; Soviets; local governments; history of Tatarstan

\section{REFERENCES}

Alekseev, I. E. (2012) Revoliutsionnye sobytiia fevralia - marta 1917 g. v Kazani: reaktsiia verkhov. Russkaia narodnaia liniia. Informatsionno-analiticheskaia sluzhba. 25 April [online] Available at: http://ruskline.ru/analitika/2012/04/25/revolyucionnye_sobytiya_fevralya_marta_1917_g_ v_kazani_reakciya_verhov/ (access date: 03.10.2016). (In Russ.).

Bor'ba s anarkhiei v Kazanskoi gubernii (1917). Kamsko-Volzbskaia recb' (newspaper), no. 127, p. 3. (In Russ.).

V gubernskom zemstve (1917). Kamsko-Volzhskaia rech' (newspaper), no. 128, p. 3. (In Russ.).

V komitete obshchestvennoi bezopasnosti (1917). Kamsko-Volzhskaia rech' (newspaper), no. 92, p. 3. (In Russ.).

Valeev, R. K. (1968) Revoliutsionnoe dvizhenie v Srednem Povolzh'e v period nazrevaniia obshchenatsional' nogo krizisa (iiul' - oktiabr' 1917 g.) : Dis.... Candidate of History. Kazan'. 329, XXVII, 10 p. (In Russ.).

Volostnoe zemstvo (1917). Kamsko-Volzhskaia rech' (newspaper), no. 116, p. 3. (In Russ.).

Gorodskaia duma (1917). Kamsko-Volzhskaia rech' (newspaper), no. 49, p. 3. (In Russ.).

Dokumenty po istorii Oktiabria v Tatarii (1973), I. M. Ionenko (ed.). Kazan', Tatarskoe knizhnoe izdatel'stvo. 212 p. (In Russ.).

Ivanov, I. N. (1923) Kak my rabotali. Kommunisticheskii put', no. 2 (22), pp. 64-65. (In Russ.).

Kabytova, N. N. (1999) Vlast' i obshchestvennye organizatsii Povolzb'ia v 1917 godu : Dis.... Doctor of History. Samara. 462 p. (In Russ.).

Mansurov, R. Z. (2006) Fevral'skaia revoliutsiia $v$ Kazanskoi gubernii kak faktor novoi obshchestvenno-politicheskoi situatsii v krae: Dis. ... Candidate of History. Kazan'. 188 p. (In Russ.).

Nachal'nik gorodskoi militsii (1917). Kamsko-Volzhskaia rech' (newspaper), no. 53, p. 4. (In Russ.).

Organizatsiia Komiteta obshchestvennoi bezopasnosti v Kazani (1917). Kamsko-Volzbskaia recb' (newspaper), no. 52, p. 3. (In Russ.).

Rukovodiashchie ukazaniia pravitel'stva ob ustroenii mestnoi vlasti (1917). Kamsko-Volzbskaia rech' (newspaper), no. 63, p. 3. (In Russ.).

Telegramma gruppy gubernskikh glasnykh (1917). Kamsko-Volzhskaia rech' (newspaper), no. 107, p. 3. (In Russ.).

Khalilova, T. V. (2000) Regional'noe liderstvo $i$ politicheskaia kul'tura (na materialakb Kazanskoi gubernii). Fevral' 1917 - iiul' 1918 gg. : Dis. ... Candidate of History. Kazan'. 205 p. (In Russ.).

Khronika (1917a). Kamsko-Volzbskaia rech' (newspaper), no. 86, p. 3. (In Russ.).

Khronika (1917b). Kamsko-Volzbskaia rech' (newspaper), no. 89, p. 3. (In Russ.). 
Khronika (1917c). Kamsko-Volzbskaia recb’ (newspaper), no. 98, p. 3. (In Russ.). (In Russ.).

Tsarevokokshaisk. Gorodskie vybory (1917). Kamsko-Volzhskaia rech' (newspaper), no.138, p. 4.

Submission date: 27.01.2017.

Миронова Елена Валерьевна - кандидат исторических наук, старший научный сотрудник Отдела историко-культурного наследия народов Республики Татарстан Института истории им. Ш. Марджани Академии наук Республики Татарстан. Адрес: 420014, Россия, г. Казань, ул. Батурина, А. 7. Тел: +7 (843) 2929199. Эл. адрес: Yelena.Mironova@yandex.ru

SPIN-код РИНЦ: 9654-1339; ORCID 0000-0003-2818-8490

Mironova Elena Valerievna, Candidate of History, Senior Research Scientist, Department of the Study of Historical and Cultural Heritage of the Peoples of Tatarstan Republic, Sh. Marjani Institute of History, Academy of Sciences, Republic of Tatarstan. Postal address: 7, Baturina St., Kazan, Russian Federation 420014. Tel.: +7 (843) 292-91-99. E-mail: Yelena.Mironova@yandex.ru 